\title{
ALTERNATIVES TO ANTIBIOTICS: PHAGE LYTIC ENZYMES AND PHAGE THERAPY
}

\author{
Nazarov PA ${ }^{\otimes}$ \\ Belozersky Institute of Physico-Chemical Biology, \\ Lomonosov Moscow State University, Moscow, Russia
}

\begin{abstract}
Multiple drug resistance of nosocomial bacterial strains provoked by the unwise and uncontrolled use of antibiotics in medicine and agriculture seriously threatens modern healthcare: minor and trivial infections are about to kill again. A solution may lie in the development of new alternatives to antibiotics. This review highlights the most interesting approaches to the development of antibacterial drugs focusing on the most promising ones, such as phage therapy and phage lytic enzymes (lysins).
\end{abstract}

Keywords: antibiotic, bacterophage, phage lysin, phage therapy, antibiotic treatment, multiple drug resistance

Funding: this work was supported by the Russian Science Foundation (Grant ID 14-50-00029).

Acknowledgement: the author wishes to thank the researchers from the Laboratory of Membrane Biophysics (Department of Bioenergetics, Belozersky Institute of Physico-Chemical Biology), the Laboratory of Molecular Bioengineering (Shemyakin-Ovchinnikov Institute of Bioorganic Chemistry) and the Laboratory of Bacteriophage Genetics (Mechnikov Research Institute of Vaccines and Sera) for discussing with him some aspects of the use of bacteriophages, phage lysins and antibacterial photodynamic therapy.

$\triangle$ Correspondence should be addressed: Pavel Nazarov

ul. Narimanovskaya 22, k,3, kv. 294, Moscow, 117997; nazarovpa@gmail.com

Received: 23.01.2018 Accepted: 28.01.2018

DOI: $10.24075 /$ brsmu.2018.002

\section{АЛЬТЕРНАТИВЫ АНТИБИОТИКАМ: ЛИТИЧЕСКИЕ ФЕРМЕНТЫ БАКТЕРИОФАГОВ И ФАГОВАЯ ТЕРАПИЯ}

\author{
П. А. Назаров $\bowtie$ \\ Научно-исследовательский институт физико-химической биологии им. А. Н. Белозерского, \\ Московский государственный университет им. М. В. Ломоносова, Москва
}

\begin{abstract}
Множественная лекарственная устойчивость госпитальных штаммов бактерий, возникшая в результате неразумного неконтролируемого применения антибиотиков в медицине и сельском хозяйстве, представляет одну из серьезнейших угроз для современного здравохранения: привычные инфекции вновь могут убивать, как раньше. Решение проблемы может быть найдено в процессе разработки альтернатив антибиотикам. В обзоре приведены краткие сведения о наиболее интересных подходах к созданию новых антибактериальных средств и подробно проанализированы наиболее преспективные из них, такие как фаговая терапия и литические ферменты бактериофагов (фаголизины).
\end{abstract}

Ключевые слова: антибиотик, бактериофаг, фаголизин, фаговая терапия, антибиотикотерапия, множественная лекарственная устойчивость

Финансирование: работа выполнена при поддержке Российского научного фонда (грант 14-50-00029).

Благодарности: автор благодарит сотрудников лаборатории биофизики мембран, отдела биоэнергетики НИИ ФХБ им. А. Н. Белозекрского МГУ, лаборатории молекулярной биоинженерии ИБХим. М. М. Шемякина иЮ. А. Овчинникова РАН и лаборатории генетики бактериофагов НИИ вакцин и сывороток им. И. И. Мечникова за обсуждения некоторых аспектов использования бактериофагов, фаголизинов и антибактериальной фотодинамической терапии.

$\bigotimes$ Для корреспонденции: Назаров Павел Александрович

ул. Наримановская, д. 22, к. 3, кв 294, г. Москва, 117997; nazarovpa@gmail.com

Статья получена: 23.01.2018 Статья принята к печати: 28.01.2018

DOI: $10.24075 /$ vrgmu.2018.002

The antibiotic era: from victory to defeat

Back in the early 19th century an opinion prevailed that disease is caused by imbalances in the body. It was only in the midcentury that Louis Pasteur linked infections to their causative agents, germs. The day in 1928 when penicillin was discovered by the British bacteriologist Alexander Fleming became a milestone in the history of medicine, marking the advent of the antibiotic era. Antibiotics were initially seen as a universal remedy, a super weapon capable of turning the tide in the war against infectious diseases. But the euphoria did not last long. As our knowledge accumulated, more new antibiotics were discovered with various mechanisms of action, different properties and spectra of activity; but bacteria struck back by developing resistance to those drugs, frustrating the efforts of researchers and doctors [1]. So hopes were pinned on lastresort antibiotics, such as colistin and daptomycin.

In May 2015 the World Health Organization (WHO) admitted that bacterial resistance to antibiotics was the underlying cause of the ongoing healthcare crisis and proposed the Global Action Plan on Antimicrobial Resistance [2]. However, it was only a few months after that a mobile colistin-resistance gene was discovered in November 2015 [3]. A similar report followed in October 2016 describing a daptomycin-resistant Staphilococcus aureus strain capable of inactivating the antibiotic by releasing membrane phospholipids into the surrounding environment once they have bound daptomycin [4]. In September 2016, a month before that report, an 
American patient died of sepsis caused by the gram-negative "superbacteria" Klebsiella pneumoniae resistant to all 26 antibiotics approved in the US [5]. The analysis of all known antibiotics and their therapeutic combinations published by $\mathrm{WHO}$ in 2017 [6] uncovered a sad truth: there is currently no cure for infections caused by gram-negative multidrugresistant bacteria. Last-resort antibiotics, the defense we thought reliable, no longer work, and trivial infections can kill once again. This urges us to develop novel antibiotics or start searching for an alternative that will be just as effective.

\section{Sources for new antibiotics}

Antibiotics are natural, synthetic or semisynthetic chemicals whose small concentrations are capable of inhibiting microbial growth. The primary source of clinically important antibiotics is actinomycetes and sometimes non-mycelial bacteria, so these microorganisms may still have something new to offer. Another way to discover a novel antibiotic is a screening for a candidate chemical structure and predicting its orientation and position in the active site of a target protein.

That said, the search for novel antibiotics has almost stopped, and for a few understandable reasons. First, most antibiotics target one of three key prokaryotic metabolic pathways and processes, including protein biosynthesis, DNA replication and bacterial cell wall synthesis [7]. The majority of possible approaches to these targets have already been proposed and scrutinized. Besides, there is always a risk of spontaneous mutations in bacteria that can ruin years of efforts spent in a scientific lab and incur additional costs. Second, to discover a single antibiotic, one has to analyze about a million new actinomycetes [8], which is a very costly procedure.

Over $90 \%$ of all bacterial species found in the environment cannot be cultured in a lab under standard conditions [9]. However, recently it has become possible to create specific conditions favorable for such bacteria in order to identify producers of yet unknown antibiotics among those species. This gave rise to two conceptually different search strategies: screening for a source of new antibiotics among unculturable bacteria and production of novel synthetic antibiotics. Both strategies are starting to pay off. For example, screening of uncultured soil bacteria has revealed a previously unknown antibiotic (teixobactin) that kills gram-positive bacteria [10]. Another antibiotic PEG-2S that inhibits $\mathrm{Na}^{+}$translocating $\mathrm{NADH}$ :ubiquinone oxidoreductase has been synthesized in the lab [11].

Of particular interest are synthetic antibiotics targeting bacterial bioenergetics [12]. In 2012, the Food and Drug Administration (USFDA) approved bedaquiline synthesized after 4 decades of research for the treatment of tuberculosis. This drug targets mycobacterial ATP synthase suppressing bacterial bioenergetics, which is causing death for the affected cells [13].

Based on the symbiotic theory a supposition was made that antioxidants that induce collapse of mitochondrial membrane potential can be effective against bacteria. Lately it has been found that the antioxidant SkQ1, a synthetic triphenyl phosphonium-based compound, can kill bacteria by decreasing their membrane potential $[14,15]$.

\section{Alternatives to antibiotics}

In spite of the astonishing variety of approaches to the discovery of effective alternatives to antibiotics and more than ten years of painstaking research, there have been no serious breakthroughs in the therapy of infections. Few candidate substitutes seem to work.

Among the most interesting alternatives to antibiotics are vaccines, antibodies, probiotics, immunostimulants, photosensitizers, natural bacteriophages, phage lytic enzymes, synthetic bacteriophages, antimicrobial peptides, hostdefense peptides, antibiofilm compounds, multidrug efflux pump inhibitors, immunosuppressants, liposome entrapment of toxins, metal chelators, antibacterial nucleic acids, antiresistance nucleic acids, and antibacterial peptides. This list is not exhaustive, though.

Based on the evaluation of clinical potential and relative simplicity of use, a conclusion can be drawn that phage lysins and multidrug efflux pump inhibitors are the most promising therapeutic alternatives to antibiotics, while vaccines and antibodies seem to have a good potential as prevention tools, and probiotics can be used for both treatment and disease prevention. Bacteriophages, antibiofilm compounds, antimicrobial peptides and photosensitizers also hold promise; however, it is not clear yet whether they can enter the market as finished pharmaceutical products to replace existing antibiotics. There are also doubts about immunostimulants that are sometimes used for disease prevention or as complementary drugs: their clinical significance is yet to be elucidated; therefore, they do not seem to be an adequate substitute for antibiotics.

Many of the approaches listed above are either undergoing experimental trials or exist as theories. More information about them can be found in the review [16] ordered by the Wellcome Trust foundation (UK) and prepared by the researchers from academic circles and the pharmaceutical industry. In this article we focus on the most promising and interesting alternatives to antibiotics, including vaccines, antibodies, multidrug efflux pump inhibitors, photosensitizers, bacteriophages and phage lysins.

\section{Vaccines}

Vaccines are a well-established and effective method of disease prevention. In 2015 the novel multicomponent vaccine Bexsero (GlaxoSmithKline Biologicals, UK) against Neisseria meningitidis was introduced into the national infant immunization program in the UK. Neisseria meningitidis is the causative agent of pediatric meningitis and bacteriaemia. Because its capsular polysaccharide MenB, which is a virulence factor, resembles human cell adhesion molecules, effective induction of antibodies against meningococcal infection is a difficult task. A group of British researchers managed to solve it by conducting a bioinformatic search for a candidate antigen. The antigen contained in the outer membrane vesicles was later shown to elicit sustained immune response upon vaccination. The approach used by the British researchers is referred to as reverse vaccinology. Bexsero is effective against $73 \%$ to $88 \%$ of group B meningococcal strains (MenB) [17]. That said, it is still very unlikely that antibiotics will be fully replaced by such vaccines in the nearest future.

\section{Antibodies}

A wide range of unique properties makes antibodies a keystone of contemporary medicine. Pathogen-specific monoclonal antibodies are either used independently for disease prevention or in combination with antibiotics to treat bacterial infections [18]. Antibodies neutralize the effects of bacterial toxins [19-22]; they can also be directed against bacterial antigens [23-25] and quorum-sensing signals [26, 27]. Together, traditional antibiotics and antibodies open new possibilities for 
inhibiting biofilm formation enhancing the effect of antibioticbased treatment and can be employed for combating persister cells insensitive to antibiotics [28, 29].

\section{Multidrug efflux pump inhibitors}

Although these compounds were known before, they are now receiving closer attention $[30,31]$ owing to the peculiar interactions between the substrates of multidrug efflux pumps and their inhibitors [15, 32]. Efflux pump inhibitors are a conceptually new approach to fighting bacteria not mentioned in the review [16], helping to reduce therapeutic concentrations of antibiotics administered to a patient by an order of magnitude or two. This phenomenon was first demonstrated using a novel antibiotic SkQ1, with pump inactivation leading to a 50-fold reduction in its minimum inhibitory concentrations. The bad news is that normally several pumps are involved in pumping antibiotics out, and the inhibitors often affect a multitude of different pumps simultaneously. Importantly, SkQ1 is recognized only by the main multidrug efflux pump of Escherichia coli, AcrAB-TolC [15]. Indeed, the use of efflux pump inhibitors provides a solution to the problem of antibiotic resistance.

\section{Photosensitizers}

Antimicrobial photodynamic therapy or inactivation (aPDT or aPDI) is new effective method of killing gram-negative and gram-positive bacteria and yeast [33-36]. aPDI employs a non-thermal reaction induced by the interactions between visible light photons and a photosensitizer, such as methylene blue, chlorin, porphyrin, chlorophyll or their derivatives, in the presence of oxygen. Reactive oxygen species produced as shown in Fig. 1 effectively kill bacterial cells, including Pseudomonas aeruginosa. This therapy is in particular demand in dentistry and dermatology [36] where it can replace local antibiotic treatment.

\section{Phage therapy}

Bacterial viruses or bacteriophages constitute the largest group of viruses with double-stranded genomic DNA, although there are phages with single stranded DNA and single/doublestranded RNA [37]. In total, the number of phages is estimated to be as high as $10^{31}-10^{32}$ [38]. They play an important role in the regulation of the world's bacterial population. Phages kill $20-40 \%$ of sea bacteria per day [39]. The use of phages as therapeutic agents was proposed and successfully tested by Twort [40], D'Herelle [41], Bruynoghe and Maisin [42] in the early 20th century. However, phages did not become a popular treatment option at that time largely because antibiotics kept gaining ground and there was a lack of theoretical knowledge to explain phages' failure in clinical trials [43].

According to the contemporary views, phages used for treating bacterial infections must meet a few requirements: 1) they have to be lytic; 2) their therapeutic concentrations must be calculated for each particular infection; 3) a phage receptor involved must be well studied; 4) the final formulation must be free of bacteria and 5) contain viable bacteriophage particles [44-46]. The positive effect of phage therapy, i.e. reduction in the pathogen count down to the level at which the organism can handle the infection on its own [47], varies between individuals depending at the same time on a few other factors, which prevents phages from entering American and European markets [46].

Both bacteriophages and antibiotics directly attack bacteria; therefore, their effectiveness can be compared. Advantageously, bacteriophages are more specific for certain bacterial strains, such as Clostridium difficile that causes intestinal infections or diarrhea following antibiotic treatment [48]. Also, phage therapy is more sparing than antibiotic-based therapies $[49,50]$. However, if infection is caused by multiple different bacteria, as is the case with wounds, bacteriophages are far less effective than antibiotics [51].

In the experiment [52] E. coli were infected with bacteriophages collected in two geographically distant regions: Mexica and Bangladesh. The tested phages turned to be highly specific for bacteria from their home region [52]. However, no significant differences were observed in the outcome of two different treatments (with a Russian bacteriophage cocktail and a placebo) applied to the cohort of 160 Bangladeshi children with E. coli-associated diarrhea [53]. Bacteriophages directed against antibiotic-resistant bacterial strains are easier to find in those regions where these bacteria are indigenous [54], which
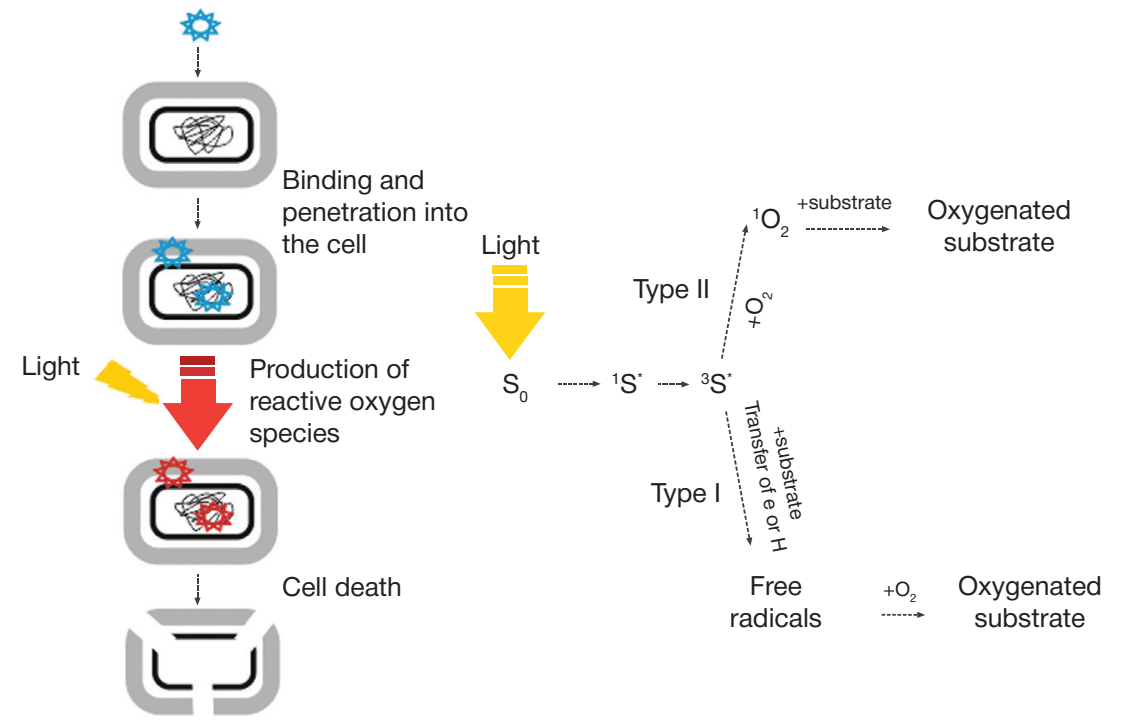

Fig. 1. Schematic illustration of antibacterial photodynamic therapy (left). Photodynamic effects explained on the molecular level (right). Upon absorbing a photon, a photosensitizer molecule $\left(\mathrm{S}_{0}\right)$ enters a short-lived excited singlet state $\left({ }^{1} \mathrm{~S}^{\star}\right)$, moving then to a triplet state $\left({ }^{3} \mathrm{~S}^{\star}\right)$. After that, two scenarios are possible: either ${ }^{3} \mathrm{~S}^{\star}$ reacts with the substrate and intermittent radicals are produced that damage cell structures and macromolecules inside the cell (type I), or energy from ${ }^{3} \mathrm{~S}^{*}$ is transferred to oxygen, and reactive singlet oxygen ${ }^{1} \mathrm{O}_{2}$ is produced that also damages cell structures or its macromolecules 
provides a new insight into the problem of antibiotic resistance and the use of phage therapy.

An idea to use bacteriophages for treating infections caused by biofilm-forming bacteria seems quite attractive. Antibiotics are not the best option here: they inhibit biofilm formation only when administered in high toxic doses [55]. Experiments in vitro have demonstrated that bacteriophages prevent formation of biofilms and even destroy them, especially in the case of Listeria monocytogenes, P. aeruginosa and Staphylococcus epidermidis [56, 57]

To predict possible complications or adverse effects of phage therapy, one should be aware of all nuances of phage biology and genome since many phages contain genes coding for virulence factors or toxins [58] or conferring resistance to antibiotics [59-62]. Phage therapy is difficult and requires more caution than antibiotic treatment because of the phenomena of phage-associated botulinum toxins [59], diphtheria toxins [58], cholera toxins [63], and phage-triggered conversion of non-toxic bacteria into toxic [64]. It is believed that life cycles of bacteriophages (Fig. 2) can vary from lytic to lysogenic, including pseudo lysogenic and defective $[65,66]$. The genomic analysis of the gigantic bacteriophage $P$. aeruginosa [67-69] has demonstrated that its gene products very much resemble proteins with yet uncharacterized function produced by other organisms.

To sum up, complicated life cycles, a risk of conversion and resistance gene transfer and the variability of phages, as well as mutations in the bacterial population, render phage therapy somewhat unreliable and unpopular, in spite of its good clinical potential.

\section{Phage lytic enzymes (phage lysins)}

A bacterial cell envelope is a barrier in the way of bacteriophage DNA that enters the cell in order to infect it or is released back into the surrounding environment as a viral particle. The cell envelope is a complex organized system of lipid and peptidoglycan layers protecting the cell from the invasion of foreign agents. The cell envelope of gram-negative bacteria has three components, including the inner plasma membrane, peptidoglycans and the outer membrane [70, 71], while the cell envelope of gram-positive microorganisms consists of only two components and misses the outer membrane.

The hardest to penetrate is the peptidoglycan layer built from alternating residues of $\mathrm{N}$-acetylglucosamine and $\mathrm{N}$-acetylmuramic acid linked by $\beta-1,4$-glycosidic bonds and short peptide chains. Linked together, peptidoglycan blocks (referred to as murein) form a gigantic macromolecule that ensures mechanical stability of the layer and its impermeability to viruses and toxic factors with big molecular weight [37, 70, 71]. Therefore, to get inside the cell, the phage has to locally disrupt the integrity of cell membranes and the peptidoglycan layer. This is done by lytic enzymes called bacteriophage lysins (phage lysins, endolysins or virolysins).

Importantly, the peptidoglycan layer of an infected cell is lysed in a two-step process [72] which includes "lysis from without" followed by phage DNA passage into the cell and "Iysis from within" facilitating release of new phage particles into the environment. Normally, the first type of lysis is performed by a capsid-associated phage lysin, such as the gp5 baseplate protein produced by the T4 bacteriophage; this lysin has a functional domain with lytic properties [73, 74]. "Lysis from without" is limited to a particular site on the membrane and lasts just enough time for phage DNA to enter the cell and not be killed by the phage. "Lysis from within" is usually performed by a soluble phage lysin and is not site-restricted but very limited in time. It follows the massive synthesis of phage lysins in the cell and is activated in parallel with holin integration into the cell membrane. Holin is a regulatory protein that forms nonselective pores in the bacterial membrane. These pores disrupt bacterial metabolism and make the peptidoglycan layer vulnerable to phage lysins, which results in the total lysis of the layer, cell damage and release of phage particles into the environment [75-77].

Soluble phage lysins triggering massive "lysis from within" are interesting candidate alternatives to antibiotics: they can effectively lyse peptidoglycan and, unlike phages, do not depend on holin presence.

There are a few classifications of phage lysins [78-85], including the one based on the mechanism of their action: 1) lysozymes, which hydrolyze $\beta-1,4$-bonds between the residues of $\mathrm{N}$-acetylmuramic acid and $\mathrm{N}$-acetylglucosamine in the peptidoglycan molecule; they are subdivided into muramidases and lytic transglycosylases; 2) N-acetylmuramoyl-L-alanine amidases, which hydrolyze the amide bond between $\mathrm{N}$-acetylmuramic acid and L-alanine; 3) peptidases, which hydrolyze the peptide bond between peptidoglycan amino acids, and 4) esterases (Fig. 3).

A study of autolytic enzymes of $S$. pneumoniae revealed that phage lysins have a modular structure, with one domain recognizing the site of lysis and the other cleaving peptidoglycan [86]. The modular structure appeared to be typical for both previously discovered and new phage lysins [87-89], which was later confirmed by genetic engineering experiments involving rearrangement and combination of functional domains [90].

Of course, not all phage lysins have equal potential to become therapeutic agents but some of their properties, such as the ability of PlySs2 to retain its function after 10 hours of freezing and thawing cycles [91] and the ability of PlyG to attack endospores of Bacillus anthracis [92], make phage lysins an interesting object for research. They are also species-specific, i. e. they kill only those bacterial (sub)species that are targeted by their phages $[93,94]$.

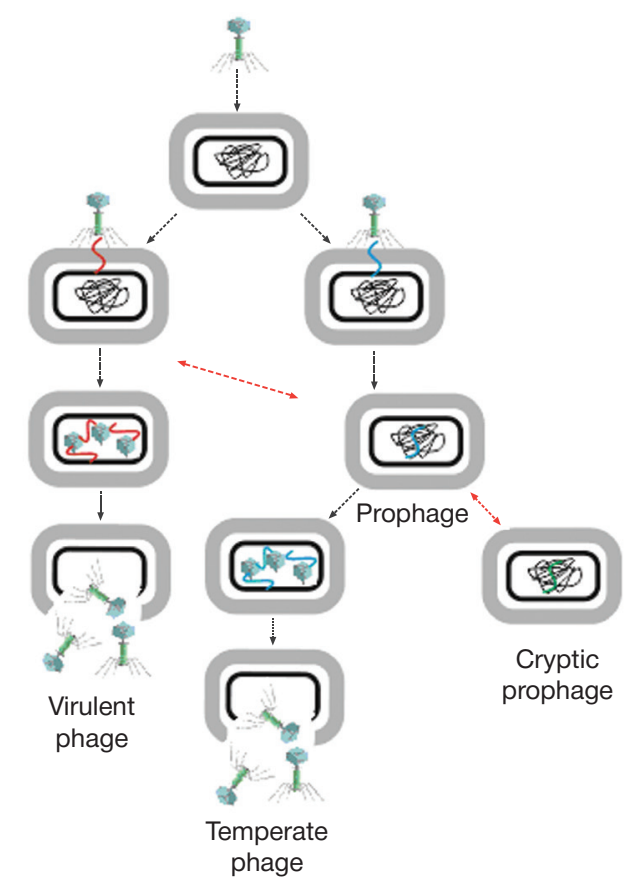

Fig. 2. Possible scenarios of phage infection in the bacterial population Reversible stages are shown in red (mutations, premature sequence termination in prophages, deletions, insertions, etc.) 
Considering the modular structure of natural phage lysins, through simple genetic modifications researchers managed to design chimeric phage lysins for treating complex bacterial infections caused by methicillin-resistant S. aureus (MRSA) [95]. Also, combined with low molecular weight antibiotics, such as penicillin or gentamycin, phage lysin Cpl-1 can totally eliminate penicillin-resistant pneumococci [96].

However, the absence of phage machinery facilitating passage through the bacterial cell wall restricts the use of phage lysins. The outer membrane of gram-negative bacteria reduces the therapeutic effect of phage lysins almost to nothing [94]. However, they do work in gram-positive bacteria. In addition, there is a risk of antibody production in response to phage lysins, which may interfere with phage lysin "mission". Both in vitro and in vivo experiments demonstrate that antibodies impede but not totally block lysis of bacterial cells by phage lysins [97], which may be explained by the fact that the affinity of the latter to their substrates is possibly higher than the affinity of a generated antibody to the enzyme.

\section{CONCLUSION}

Although there are a lot of promising alternatives to antibiotics, none of them seems to be a perfect substitute for antimicrobial drugs. All of them are not so safe, predictable, controllable, easy to use or effective. Still, it is obvious that development of alternative approaches to treating bacterial infections is a vital necessity for today's healthcare. Combination therapies will probably win over others due to the synergistic effect of their components: antibiotics and their alternatives working together.
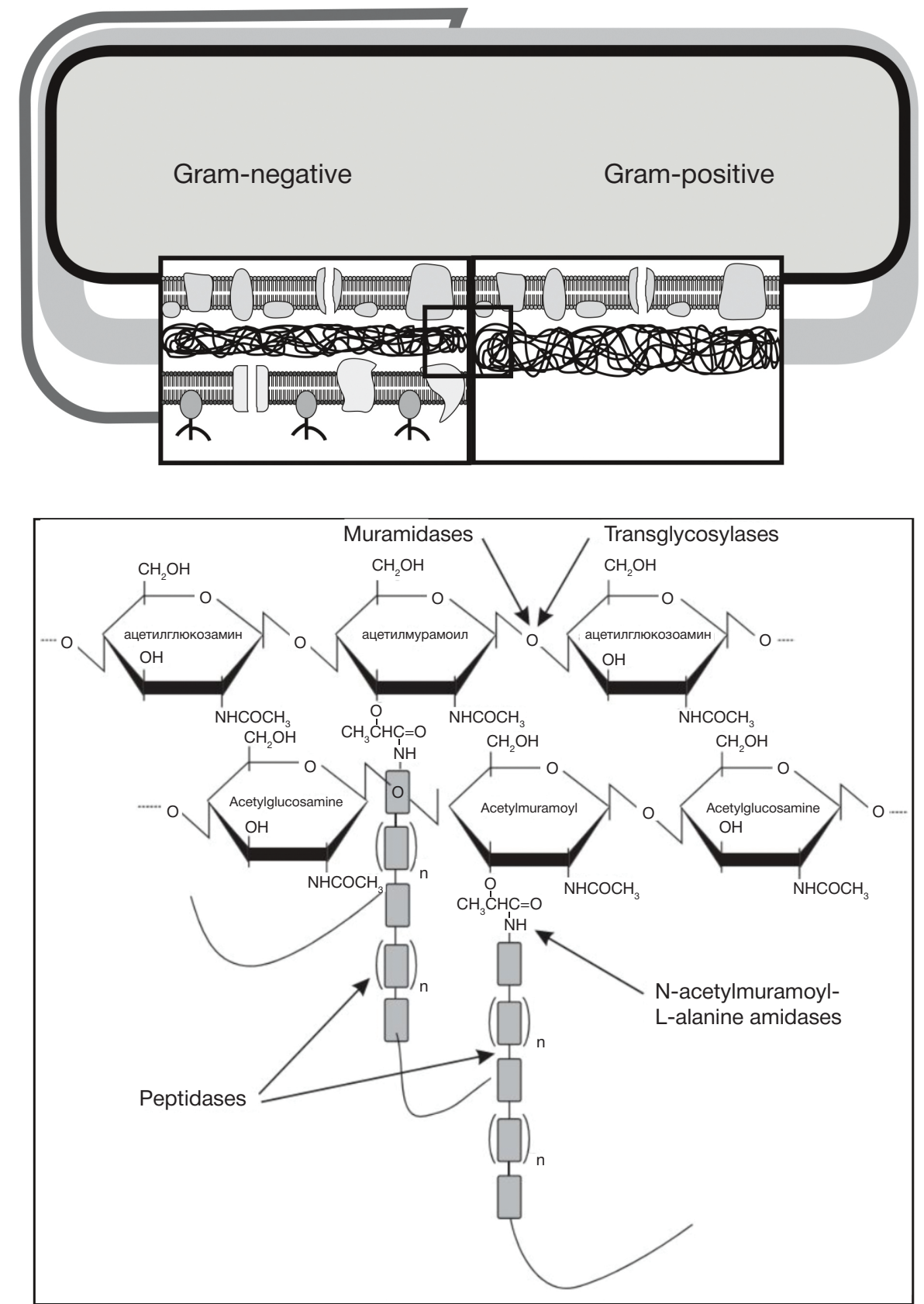

Fig. 3. Schematic of bacterial cell envelopes and phage lysin classes that degrade the peptidoglycan layer 
1. Nazarov PA. Chelovechestvo mozhet vyigrat' voynu protiv bakteriy. Kommersant Nauka. 2017; (5): 20-2. Russian.

2. World Health Organization. Global action plan on antimicrobial resistance. Geneva, Switzerland: WHO Document Production Services; 2015. 21 p. Available from: http://www.who.int/ antimicrobial-resistance/publications/global-action-plan/en/.

3. Liu YY, Wang Y, Walsh TR, Yi LX, Zhang R, Spencer $J$ et al. Emergence of plasmid-mediated colistin resistance mechanism MCR-1 in animals and human beings in China: a microbiological and molecular biological study. Lancet Infect Dis. 2016 Feb; 16 (2): 161-8. DOI: 10.1016/S1473-3099(15)00424-7.

4. Pader V, Hakim S, Painter KL, Wigneshweraraj S, Clarke TB, Edwards AM. Staphylococcus aureus inactivates daptomycin by releasing membrane phospholipids. Nat Microbiol. 2016 Oct 24; 2: 16194. DOI: 10.1038/nmicrobiol.2016.194.

5. Chen L, Todd R, Kiehlbauch J, Walters M, Kallen A. Notes from the Field: Pan-Resistant New Delhi Metallo-Beta-LactamaseProducing Klebsiella pneumoniae - Washoe County, Nevada, 2016. MMWR Morb Mortal Wkly Rep. 2017 Jan 13; 66 (1): 33. DOI: 10.15585/mmwr.mm6601a7.

6. World Health Organization. Antibacterial agents in clinical development. Geneva, Switzerland: WHO Document Production Services; 2017. 48 p. Availble from: http://apps.who.int/iris/ bitstream/10665/258965/1/WHO-EMP-IAU-2017.11-eng. pdf?ua $=1$.

7. Kohanski MA, Dwyer DJ, Collins JJ. How antibiotics kill bacteria: from targets to networks. Nat Rev Microbiol. 2010 Jun; 8 (6): 423-35. DOI: 10.1038/nrmicro2333.

8. Baltz $\mathrm{RH}$. Antimicrobials from Actinomycetes: Back to the Future. Microbe. 2007; 2 (3): 125-31.

9. Lewis K. Platforms for antibiotic discovery. Nat Rev Drug Discov. 2013 May; 12 (5): 371-87. DOI: 10.1038/nrd3975.

10. Ling LL, Schneider T, Peoples AJ, Spoering AL, Engels I, Conlon BP et al. A new antibiotic kills pathogens without detectable resistance. Nature. 2015 Jan 22; 517 (7535): 455-9. DOI: 10.1038/nature14098.

11. Dibrov P, Dibrov E, Maddaford TG, Kenneth M, Nelson J, Resch $\mathrm{C}$ et al. Development of a novel rationally designed antibiotic to inhibit a nontraditional bacterial target. Can J Physiol Pharmacol. 2017 May; 95 (5): 595-603. DOI: 10.1193/cjpp2016-0505

12. Hards K, Cook GM. Targeting bacterial energetics to produce new antimicrobials. Drug Resistance Updates. 2018; 36: 1-12.

13. Jones D. Tuberculosis success. Nat Rev Drug Discov. 2013; 12 (3): 175-6.

14. Khailova LS, Nazarov PA, Sumbatyan NV, Korshunova GA, Rokitskaya TI, Dedukhova VI et al. Uncoupling and Toxic Action of Alkyltriphenylphosphonium Cations on Mitochondria and the Bacterium Bacillus subtilis as a Function of Alkyl Chain Length. Biochemistry (Mosc). 2015 Dec; 80 (12): 1589-97. DOI: 10.1134/ S000629791512007X

15. Nazarov PA, Osterman IA, Tokarchuk AV, Karakozova MV, Korshunova GA, Lyamzaev KG et al. Mitochondria-targeted antioxidants as highly effective antibiotics. Sci Rep. 2017 may 3; 7 (1): 1394. DOI: 10.1038/s41598-017-00802-8.

16. Czaplewski L, Bax R, Clokie M, Dawson M, Fairhead $H$, Fischetti VA et al. Alternatives to antibiotics-a pipeline portfolio review. Lancet Infect Dis. 2016 Feb; 16 (2): 239-51. DOI: 10.1016/ S1473-3099(15)00466-1.

17. Ladhani SN, Campbell H, Parikh SR, Saliba V, Borrow R, Ramsay $M$. The introduction of the meningococcal B (MenB) vaccine (Bexsero ${ }^{\oplus}$ ) into the national infant immunisation programme--New challenges for public health. J Infect. 2015 Dec; 71 (6): 611-4. DOI: 10.1016/j.jinf.2015.09.035.

18. DiGiandomenico A, Sellman BR. Antibacterial monoclonal antibodies: the next generation? Curr Opin Microbiol. 2015 Oct; 27: 78-85. DOI: 10.1016/j.mib.2015.07.014.

19. Babcock GJ, Broering TJ, Hernandez HJ, Mandell RB, Donahue $\mathrm{K}$, Boatright $\mathrm{N}$ et al. Human monoclonal antibodies directed against toxins $\mathrm{A}$ and $\mathrm{B}$ prevent Clostridium difficileinduced mortality in hamsters. Infect Immun. 2006 Nov; 74 (11):
6339-47. DOI: 10.1128/IAl.00982-06.

20. Foletti D, Strop P, Shaughnessy L, Hasa-Moreno A, Casas MG, Russell $\mathrm{M}$ et al. Mechanism of action and in vivo efficacy of a human-derived antibody against Staphylococcus aureus alphahemolysin. J Mol Biol 2013 May 27; 425 (10): 1641-54. DOl: 10.1016/j.jmb.2013.02.008.

21. Oganesyan V, Peng L, Damschroder MM, Cheng L, Sadowska A, Tkaczyk C et al. Mechanisms of neutralization of a human anti-alpha toxin antibody. J Biol Chem. 2014 Oct 24; 289 (43): 29874-80. DOI: 10.10174/jbc.M114.601328.

22. Lowy I, Molrine DC, Leav BA, Blair BM, Baxter R, Gerding DN et al. Treatment with monoclonal antibodies against Clostridium difficile toxins. N Engl J Med. 2010 Jan 21; 362 (3): 197-205. DOI: 10.1056/NEJMoa0907635.

23. Szijártó V, Lukasiewicz J, Gozdziewicz TK, Magyarics Z, Nagy E, Nagy G. Diagnostic potential of monoclonal antibodies specific to the unique O-antigen of multidrug-resistant epidemic Escherichia coli clone ST131-O25b:H4. Clin Vaccine Immunol. 2014 Jul; 21 (7): 930-9. DOI: 10.1128/CVI.00685-13.

24. Kelly-Quintos C, Cavacini LA, Posner MR, Goldmann D, Pier GB. Characterization of the opsonic and protective activity against Staphylococcus aureus of fully human monoclonal antibodies specific for the bacterial surface polysaccharide polyNacetylglucosamine. Infect Immun. 2006 May; 74 (5): 2742-50. DOI: 10.1128/IAI.74.5.2742-2750.2006.

25. Hazenbos WL, Kajihara KK, Vandlen R, Morisaki JH, Lehar SM, Kwakkenbos MJ et al. Novel staphylococcal glycosyltransferases SdgA and SdgB mediate immunogenicity and protection of virulence-associated cell wall proteins. PLoS Pathog. 2013; 9 (10): e1003653. DOI: 10.1371/journal.ppat.1003653.

26. Palliyil S, Downham C, Broadbent I, Charlton K, Porter AJ. Highsensitivity monoclonal antibodies specific for homoserine lactones protect mice from lethal Pseudomonas aeruginosa infections. Appl Environ Microbiol. 2014 Jan; 80 (2): 462-9. DOI: 10.1128/ AEM.02912-13.

27. Palliyil S. Generation of High-Sensitivity Monoclonal Antibodies Specific for Homoserine Lactones. Methods Mol Biol. 2018; 1673: 325-52. DOI: 10.1007/978-1-4939-7309-5_25.

28. Varshney AK, Wang X, Maclntyre J, Zollner RS, Kelleher K, Kovalenko OV et al: Humanized staphylococcal enterotoxin B (SEB)-specific monoclonal antibodies protect from SEB intoxication and Staphylococcus aureus infections alone or as adjunctive therapy with vancomycin. J Infect Dis. 2014 Sep 15; 210 (6): 973-81. DOI: 10.1093/infdis/jiu198.

29. Hilliard JJ, Datta V, Tkaczyk C, Hamilton M, Sadowska A, JonesNelson $O$ et al. Anti- alpha toxin monoclonal antibody and antibiotic combination therapyimproves disease outcome and accelerates healing in a Staphylococcus aureus dermonecrosis model. Antimicrob Agents Chemother. 2015 Jan; 59 (1): 299309. DOI: 10.1128/AAC.03918-14.

30. Zou L, Liu M, Wang Y, Lu J, Pang Y. Determination of in vitro synergy between linezolid and other antimicrobial agents against Mycobacterium tuberculosis isolates. Tuberculosis (Edinb). 2015 Dec; 95 (6): 839-42. DOI: 10.1016/j.tube.2015.07.003.

31. Berditsch M, Jäger T, Strempel N, Schwartz T, Overhage J, Ulrich AS. Synergistic effect of membrane-active peptides polymyxin $B$ and gramicidin $S$ on multidrug-resistant strains and biofilms of Pseudomonas aeruginosa. Antimicrob Agents Chemother. 2015 Sep; 59 (9): 5288-96. DOI: 10.1128/ AAC.00682-15.

32. Krishnamoorthy G, Leus IV, Weeks JW, Wolloscheck D, Rybenkov W, Zgurskaya HI. Synergy between Active Efflux and Outer Membrane Diffusion Defines Rules of Antibiotic Permeation into Gram-Negative Bacteria. MBio. 2017; 8 (5): e01172-17. DOI: 10.1128/mBio.01172-17.

33. Omarova EO, Nazarov PA, Firsov AM, Strakhovskaya MG, Arkhipova AY, Moisenovich MM et al. Carboranyl-Chlorin e6 as a Potent Antimicrobial Photosensitizer. PLoS One. 2015; 10 (11): e0141990. DOI: 10.1371/journal.pone.0141990.

34. Maliszewska I, Kałas W, Wysokińska E, Tylus W, Pietrzyk N, Popko $\mathrm{K}$ et al. Enhancement of photo-bactericidal effect 
of tetrasulfonated hydroxyaluminum phthalocyanine on Pseudomonas aeruginosa. Lasers Med Sci. 2018 Jan; 33 (1): 79-88. DOI: 10.1007/s10103-017-2337-0.

35. Fekrazad R, Zare H, Vand SM. Photodynamic therapy effect on cell growth inhibition induced by Radachlorin and toluidine blue O on Staphylococcus aureus and Escherichia coli: An in vitro study. Photodiagnosis Photodyn Ther. 2016 Sep;15: 213-7. DOI: 10.1016/j.pdpdt.2016.07.001

36. Sperandio FF, Huang YY, Hamblin MR. Antimicrobial photodynamic therapy to kill Gram-negative bacteria. Recent Pat Antiinfect Drug Discov. 2013 Aug; 8 (2): 108-20.

37. Miroshnikov KA, Chertkov OV, Nazarov PA, Mesyanzhinov W. Peptido-glikanliziruyushchie fermenty bakteriofagov perspektivnye protivobakterial'nye agenty. Uspekhi biologicheskoy khimii. 2006; 46: 65-98. Russian.

38. Suttle CA. Marine viruses--major players in the global ecosystem. Nat Rev Microbiol. 2007 Oct; 5 (10): 801-12. DOI: 10.1038/ nrmicro1750

39. Wittebole X, De Roock S, Opal SM. A historical overview of bacteriophage therapy as an alternative to antibiotics for the treatment of bacterial pathogens. Virulence. 2014 Jan 1; 5 (1): 226-35. DOI: 10.4161/viru.25991.

40. Twort FW. An investigation on the nature of ultramicroscopic viruses. Lancet. 1915 Dec 4; (4814): 1241-3.

41. D'Herelle F. Sur un microbe invisible antagoniste des bacilles dysentériques. C R Acad Sci (Paris). 1917; 165: 373-5. French.

42. Bruynoghe R., Maisin J. Essais de thérapeutique au moyen du bacteriophage. C R Soc Biol. 1921: 85: 1120-1. French.

43. Barrow PA, Soothill JS. Bacteriophage therapy and prophylaxis: rediscovery and renewed assessment of potential. Trends Microbiol. 1997 Jul; 5 (7): 268-71. DOI: 10.1016/S0966842X(97)01054-8.

44. Sulakvelidze A, Alavidze Z, Morris JG Jr. Bacteriophage Therapy. Antimicrob Agents Chemother. 2001 Mar; 45 (3): 649-59. DOl: 10.1128/AAC.45.3.649-659.2001

45. Skurnik M, Strauch E. Phage therapy: facts and fiction. Int J Med Microbiol. 2006 Feb; 296 (1): 5-14. DOI: 10.1016/j. ijmm.2005.09.002

46. Lin DM, Koskella B, Lin HC Phage therapy: An alternative to antibiotics in the age of multi-drug resistance. World J Gastrointest Pharmacol Ther. 2017 Aug 6; 8 (3): 162-173. DOI: 10.4292/ wjgpt.v8.i3.162.

47. Levin B, Bull JJ. Phage therapy revisited: the population biology of a bacterial infection and its treatment with bacteriophage and antibiotics. Am Naturalist. 1996; 147: 881-98.

48. Rea K, Dinan TG, Cryan JF The microbiome: A key regulator of stress and neuroinflammation. Neurobiol Stress. 2016 Oct; 4: 23-33. DOI: 10.1016/j.ynstr.2016.03.001

49. Mai V, Ukhanova M, Reinhard MK, Li M, Sulakvelidze A Bacteriophage administration significantly reduces Shigella colonization and shedding by Shigella-challenged mice without deleterious side effects and distortions in the gut microbiota. Bacteriophage. 2015 Aug; 5 (4): e1088124. DOl: 10.10180/21597081.2015.1088124.

50. Galtier M, De Sordi L, Maura D, Arachchi H, Volant S, Dillies MA et al. Bacteriophages to reduce gut carriage of antibiotic resistant uropathogens with low impact on microbiota composition. Environ Microbiol. 2016 Jul; 18 (7): 2237-45. DOI: 10.1111/14622920.13284

51. Servick K. Drug development. Beleaguered phage therapy trial presses on. Science. 2016 Jun 24; 352 (6293): 1506. DOI: 10.1126/science.352.6293.1506.

52. Bourdin G, Navarro A, Sarker SA, Pittet AC, Qadri F, Sultana S et al. Coverage of diarrhoea-associated Escherichia coli isolates from different origins with two types of phage cocktails. Microb Biotechnol. 2014 Mar; 7 (2): 165-76. DOI: 10.1111/17517915.12113.

53. Sarker SA, Sultana S, Reuteler G, Moine D, Descombes $P$, Charton $\mathrm{F}$ et al. Oral Phage Therapy of Acute Bacterial Diarrhea with Two Coliphage Preparations: A Randomized Trial in Children from Bangladesh. EBioMedicine. 2016 Jan 5; 4: 124-37. DOI: 10.1016/j.ebiom.2015.12.023.

54. Latz S, Wahida A, Arif A, Häfner H, Hoß M, Ritter Ket al. Preliminary survey of local bacteriophages with lytic activity against multi-drug resistant bacteria. J Basic Microbiol. 2016 Oct; 56 (10): 1117-23. DOI: 10.1002/jibm.201600108.

55. Abedon ST. Ecology of Anti-Biofilm Agents I: Antibiotics versus Bacteriophages. Pharmaceuticals (Basel). 2015 Sep 9; 8 (3): 525-58. DOI: 10.3390/ph8030525.

56. Gabisoniya TG, Loladze MZ, Nadiradze MM, Chakhunashvili NK, Alibegashvili MG, Tamarashvili NG et al. Effects of bacteriophages on biofilm formation by strains of Pseudomonas aeruginosa. Appl Biochem Microbiol. 2016; 52: 293-7.

57. Motlagh AM, Bhattacharjee AS, Goel R. Biofilm control with natural and genetically-modified phages. World J Microbiol Biotechnol. 2016 Apr; 32 (4): 67. DOI: 10.1007/s11274-016-2009-4.

58. Brüssow H, Canchaya C, Hardt WD. Phages and the evolution of bacterial pathogens: from genomic rearrangements to lysogenic conversion. Microbiol Mol Biol Rev. 2004 Sep; 68 (3): 560-602. DOI: 10.1128/MMBR.68.3.560-602.2004.

59. Penadés JR, Chen J, Quiles-Puchalt N, Carpena N, Novick RP. Bacteriophage-mediated spread of bacterial virulence genes. Curr Opin Microbiol. 2015 Feb; 23: 171-8. DOI: 10.1016/j. mib.2014.11.019.

60. Modi SR, Lee HH, Spina CS, Collins JJ. Antibiotic treatment expands the resistance reservoir and ecological network of the phage metagenome. Nature. 2013 Jul 11; 499 (7457): 219-22. DOI: 10.1038/nature12212.

61. Quirós P, Colomer-Lluch M, Martínez-Castillo A, Miró E, Argente $\mathrm{M}$, Jofre $\mathrm{J}$ et al. Antibiotic resistance genes in the bacteriophage DNA fraction of human fecal samples. Antimicrob Agents Chemother. 2014; 58 (1): 606-9. DOI: 10.1128/ AAC.01684-13.

62. Colomer-Lluch M, Jofre J, Muniesa M. Antibiotic resistance genes in the bacteriophage DNA fraction of environmental samples. PLoS One. 2011 Mar 3; 6 (3): e17549. DOI: 10.1371/journal. pone.0017549.

63. Davis BM, Waldor MK. Filamentous phages linked to virulence of Vibrio cholerae. Curr Opin Microbiol. 2003 Feb; 6 (1): 35-42.

64. Broudy TB, Fischetti VA. In Vivo Lysogenic Conversion of ToxStreptococcus pyogenes to Tox+ with Lysogenic Streptococci or Free Phage. Infect Immun. 2003 Jul; 71 (7): 3782-6. DOI: 10.1128/IAl.71.7.3782-3786.2003.

65. Wang X, Wood TK. Cryptic prophages as targets for drug development. Drug Resist Updat. 2016 Jul; 27: 30-8. DOI: 10.1016/j.drup.2016.06.001

66. Weinbauer MG. Ecology of prokaryotic viruses. FEMS Microbiol Rev. 2004 May; 28 (2): 127-81. DOI: 10.1016/j. femsre.2003.08.001.

67. Krylov VN, Pleteneva EL, Bourkaltseva M, Shaburova O, Volckaert G, Sykilinda N et al. Myoviridae bacteriophages of Pseudomonas aeruginosa: a long and complex evolutionary pathway. Res Microbiol. 2003 May; 154 (4); 269-75. DOl: 10.1016/S0923-2508(03)00070-6.

68. Mesyanzhinov W, Robben J, Grymonprez B, Kostyuchenko VA, Burkaltseva MV, Sykilinda NN et al. The genome of bacteriophage fKZ of Pseudomonas aeruginosa. J Mol Biol. 2002 Mar 15; 317 (1): 1-19. DOI: 10.1006/jmbi.2001.5396

69. Hertveldt K, Lavigne R, Pleteneva E, Sernova N, Kurochkina L, Korchevskii R et al. Genome comparison of Pseudomonas aeruginosa large phages. J Mol Biol. 2005 Dec 2; 354 (3): 53645. DOI: 10.1016/j.jmb.2005.08.075.

70. Navarre WW, Schneewind O. Surface proteins of gram-positive bacteria and mechanisms of their targeting to the cell wall envelope. Microbiol Mol Biol Rev. 1999 Mar; 63 (1): 174-229.

71. Beveridge TJ. Structures of gram-negative cell walls and their derived membrane vesicles. J Bacteriol. 1999 Aug; 181 (16): 4725-33.

72. Delbrück M. The Growth of Bacteriophage and Lysis of the Host. J Gen Physiol. 1940; 23 (5): 643-60.

73. Leiman PG, Chipman PR, Kostyuchenko VA, Mesyanzhinov W, Rossmann MG. Three-dimensional rearrangement of proteins in the tail of bacteriophage T4 on infection of its host. Cell. 2004 Aug 20;118 (4): 419-29. DOI: 10.1016/j.cell.2004.07.022.

74. Kanamaru S, Leiman PG, Kostyuchenko VA, Chipman PR, Mesyanzhinov W, Arisaka F et al. Structure of the cell-puncturing 
device of bacteriophage T4. Nature. 2002 Jan 31; 415 (6871): 553-7. DOI: 10.1038/415553a.

75. Roach DR, Donovan DM. Antimicrobial bacteriophage-derived proteins and therapeutic applications. Bacteriophage. $2015 \mathrm{Jul}-$ Sep; 5 (3): e1062590. DOI: 10.1080/21597081.2015.1062590.

76. Young R. Phage lysis: do we have the hole story yet? Curr Opin Microbiol. 2013 Dec; 16 (6): 790-7. DOI: 10.1016/j. mib.2013.08.008.

77. Young R. Phage lysis: three steps, three choices, one outcome. $J$ Microbiol. 2014 Mar; 52 (3): 243-58. DOI: 10.1007/s12275-0144087-z.

78. Henrissat B. A classification of glycosyl hydrolases based on amino acid sequence similarities. Biochem J. 1991 Dec 1; 280 (Pt 2): 309-16.

79. Henrissat B, Bairoch A. Updating the sequence-based classification of glycosyl hydrolases. Biochem J. 1996 Jun 1; 316 (Pt 2): 695-6.

80. Blackburn NT, Clarke AJ. Identification of four families of peptidoglycan Iytic transglycosylases. J Mol Evol. 2001 Jan; 52 (1): 78-84.

81. Höltje JV. Lytic transglycosylases. EXS. 1996; 75: 425-9.

82. Fastrez J. Phage lysozymes. EXS. 1996; 75: 35-64.

83. Weaver LH, Grütter MG, Remington SJ, Gray TM, Isaacs NW, Matthews BW. Comparison of goose-type, chicken-type, and phage-type lysozymes illustrates the changes that occur in both amino acid sequence and three-dimensional structure during evolution. J Mol Evol. 1984-1985; 21 (2): 97-111

84. Monzingo AF, Marcotte EM, Hart PJ, Robertus JD. Chitinases, chitosanases, and lysozymes can be divided into procaryotic and eucaryotic families sharing a conserved core. Nat Struct Biol. 1996 Feb; 3 (2): 133-40.

85. Jaeger $\mathrm{T}$, Arsic M, Mayer $\mathrm{C}$. Scission of the lactyl ether bond of N-acetylmuramic acid by Escherichia coli "etherase". J Bio Chem. 2005 Aug 26; 280 (34): 30100-6. DOI: 10.1074/jbc. M502208200.

86. Díaz E, López R, García JL. Chimeric phage-bacterial enzymes: a clue to the modular evolution of genes. Proc Natl Acad Sci U S A. 1990 Oct; 87 (20): 8125-9.

87. Desiere F, Lucchini S, Brüssow H. Evolution of Streptococcus thermophilus bacteriophage genomes by modular exchanges followed by point mutations and small deletions and insertions. Virology. 1998 Feb 15; 241 (2): 345-56.

\section{Литература}

1. Назаров П. А. Человечество может выиграть войну против бактерий. Коммерсант Наука. 2017; (5): 20-2.

2. World Health Organization. Global action plan on antimicrobial resistance. Geneva, Switzerland: WHO Document Production Services; 2015. 21 p. Available from: http://www.who.int/ antimicrobial-resistance/publications/global-action-plan/en/.

3. Liu YY, Wang Y, Walsh TR, Yi LX, Zhang R, Spencer J et al. Emergence of plasmid-mediated colistin resistance mechanism MCR-1 in animals and human beings in China: a microbiological and molecular biological study. Lancet Infect Dis. 2016 Feb; 16 (2): 161-8. DOI: 10.1016/S1473-3099(15)00424-7.

4. Pader V, Hakim S, Painter KL, Wigneshweraraj S, Clarke TB, Edwards AM. Staphylococcus aureus inactivates daptomycin by releasing membrane phospholipids. Nat Microbiol. 2016 Oct 24; 2: 16194. DOI: 10.1038/nmicrobiol.2016.194

5. Chen L, Todd R, Kiehlbauch J, Walters M, Kallen A. Notes from the Field: Pan-Resistant New Delhi Metallo-Beta-LactamaseProducing Klebsiella pneumoniae - Washoe County, Nevada, 2016. MMWR Morb Mortal Wkly Rep. 2017 Jan 13; 66 (1): 33. DOI: $10.15585 / \mathrm{mmw} \cdot \mathrm{mm} 6601 \mathrm{a}$.

6. World Health Organization. Antibacterial agents in clinical development. Geneva, Switzerland: WHO Document Production Services; 2017. 48 p. Availble from: http://apps.who.int/iris/ bitstream/10665/258965/1/WHO-EMP-IAU-2017.11-eng. pdf?ua $=1$.

7. Kohanski MA, Dwyer DJ, Collins JJ. How antibiotics kill bacteria:
88. Sheehan MM, Stanley E, Fitzgerald GF, van Sinderen D. Identification and Characterization of a Lysis Module Present in a Large Proportion of Bacteriophages Infecting Streptococcus thermophilus. Appl Environ Microbiol. 1999 Feb; 65 (2): 569-77.

89. Hermoso JA, Monterroso B, Albert A, Galán B, Ahrazem O, García P, et al. Structural basis for selective recognition of pneumococcal cell wall by modular endolysin from phage $\mathrm{Cp}-1$. Structure. 2003 Oct; 11 (10): 1239-49.

90. López R, García E, García P, García JL. The pneumococcal cell wall degrading enzymes: a modular design to create new lysins? Microb Drug Resist. 1997 Summer; 3 (2): 199-211.

91. Gilmer DB, Schmitz JE, Euler CW, Fischetti VA. Novel bacteriophage lysin with broad lytic activity protects against mixed infection by Streptococcus pyogenes and methicillinresistant Staphylococcus aureus. Antimicrob Agents Chemother. 2013 Jun; 57 (6): 2743-50. DOI: 10.1128/AAC.02526-12.

92. Yang H, Wang DB, Dong Q, Zhang Z, Cui Z, Deng J et al. Existence of separate domains in lysin PlyG for recognizing Bacillus anthracis spores and vegetative cells. Antimicrob Agents Chemother. 2012 Oct; 56 (10): 5031-9. DOI: 10.1128/AAC.00891-12.

93. Loeffler JM, Fischetti VA. Synergistic lethal effect of a combination of phage lytic enzymes with different activities on penicillinsensitive and -resistant Streptococcus pneumoniae strains. Antimicrob Agents Chemother. 2003 Jan; 47 (1): 375-7. DOl: 10.1128/AAC.47.1.375-377.2003.

94. Fischetti VA Bacteriophage lytic enzymes: novel anti-infectives. Trends Microbiol. 2005 Oct; 13 (10): 491-6. DOI: 10.1016/j. tim.2005.08.007.

95. Yang $\mathrm{H}$, Zhang $\mathrm{Y}$, Yu J, Huang $\mathrm{Y}$, Zhang XE, Wei H. Novel chimeric lysin with high-level antimicrobial activity against methicillinresistant Staphylococcus aureus in vitro and in vivo. Antimicrob Agents Chemother. 2014; 58 (1): 536-42. DOI: 10.1128/ AAC.01793-13

96. Djurkovic S, Loeffler JM, Fischetti VA. Synergistic killing of Streptococcus pneumoniae with the bacteriophage lytic enzyme Cpl-1 and penicillin or gentamicin depends on the level of penicillin resistance. Antimicrob Agents Chemother. 2005 Mar; 49 (3): 1225-8. DOI: 10.1128/AAC.49.3.1225-1228.2005.

97. Schmelcher M, Donovan DM, Loessner MJ. Bacteriophage endolysins as novel antimicrobials. Future Microbiol. 2012 Oct; 7 (10): 1147-71. DOI: 10.2217/fmb.12.97.

from targets to networks. Nat Rev Microbiol. 2010 Jun; 8 (6) 423-35. DOI: 10.1038/nrmicro2333.

8. Baltz RH. Antimicrobials from Actinomycetes: Back to the Future. Microbe. 2007; 2 (3): 125-31.

9. Lewis K. Platforms for antibiotic discovery. Nat Rev Drug Discov. 2013 May; 12 (5): 371-87. DOI: 10.1038/nrd3975.

10. Ling LL, Schneider T, Peoples AJ, Spoering AL, Engels I, Conlon BP et al. A new antibiotic kills pathogens without detectable resistance. Nature. 2015 Jan 22; 517 (7535): 455-9. DOI: 10.1038/nature14098.

11. Dibrov P, Dibrov E, Maddaford TG, Kenneth M, Nelson J, Resch $\mathrm{C}$ et al. Development of a novel rationally designed antibiotic to inhibit a nontraditional bacterial target. Can J Physiol Pharmacol. 2017 May; 95 (5): 595-603. DOI: 10.1193/cjpp2016-0505.

12. Hards K, Cook GM. Targeting bacterial energetics to produce new antimicrobials. Drug Resistance Updates. 2018; 36: 1-12.

13. Jones D. Tuberculosis success. Nat Rev Drug Discov. 2013; 12 (3): 175-6.

14. Khailova LS, Nazarov PA, Sumbatyan NV, Korshunova GA, Rokitskaya TI, Dedukhova VI et al. Uncoupling and Toxic Action of Alkyltriphenylphosphonium Cations on Mitochondria and the Bacterium Bacillus subtilis as a Function of Alkyl Chain Length. Biochemistry (Mosc). 2015 Dec; 80 (12): 1589-97. DOI: 10.1134/ S000629791512007X

15. Nazarov PA, Osterman IA, Tokarchuk AV, Karakozova MV, 
Korshunova GA, Lyamzaev KG et al. Mitochondria-targeted antioxidants as highly effective antibiotics. Sci Rep. 2017 may 3; 7 (1): 1394. DOI: 10.1038/s41598-017-00802-8.

16. Czaplewski L, Bax R, Clokie $M$, Dawson $M$, Fairhead $H$, Fischetti VA et al. Alternatives to antibiotics-a pipeline portfolio review. Lancet Infect Dis. 2016 Feb; 16 (2): 239-51. DOI: 10.1016/ S1473-3099(15)00466-1.

17. Ladhani $S N$, Campbell $H$, Parikh $S R$, Saliba V, Borrow $R$, Ramsay M. The introduction of the meningococcal B (MenB) vaccine $\left(\right.$ Bexsero $^{\circledR}$ ) into the national infant immunisation programme--New challenges for public health. J Infect. 2015 Dec; 71 (6): 611-4. DOI: 10.1016/j.jinf.2015.09.035.

18. DiGiandomenico A, Sellman BR. Antibacterial monoclonal antibodies: the next generation? Curr Opin Microbiol. 2015 Oct 27: 78-85. DOI: 10.1016/j.mib.2015.07.014.

19. Babcock GJ, Broering TJ, Hernandez HJ, Mandell RB, Donahue $\mathrm{K}$, Boatright $\mathrm{N}$ et al. Human monoclonal antibodies directed against toxins $\mathrm{A}$ and $\mathrm{B}$ prevent Clostridium difficileinduced mortality in hamsters. Infect Immun. 2006 Nov; 74 (11) 6339-47. DOI: 10.1128/IAI.00982-06.

20. Foletti D, Strop P. Shaughnessy L, Hasa-Moreno A, Casas MG Russell $\mathrm{M}$ et al. Mechanism of action and in vivo efficacy of a human-derived antibody against Staphylococcus aureus alphahemolysin. J Mol Biol 2013 May 27; 425 (10): 1641-54. DOl: 10.1016/.j.jmb.2013.02.008

21. Oganesyan V, Peng L, Damschroder MM, Cheng L, Sadowska A, Tkaczyk $C$ et al. Mechanisms of neutralization of a human anti-alpha toxin antibody. J Biol Chem. 2014 Oct 24; 289 (43): 29874-80. DOI: 10.10174/jbc.M114.601328.

22. Lowy I, Molrine DC, Leav BA, Blair BM, Baxter R, Gerding DN et al. Treatment with monoclonal antibodies against Clostridium difficile toxins. N Engl J Med. 2010 Jan 21; 362 (3): 197-205. DOI: 10.1056/NEJMoa0907635.

23. Szijártó V, Lukasiewicz J, Gozdziewicz TK, Magyarics Z, Nagy E, Nagy G. Diagnostic potential of monoclonal antibodies specific to the unique O-antigen of multidrug-resistant epidemic Escherichia coli clone ST131-O25b:H4. Clin Vaccine Immunol. 2014 Jul; 21 (7): 930-9. DOI: 10.1128/CVI.00685-13.

24. Kelly-Quintos C, Cavacini LA, Posner MR, Goldmann D, Pier GB. Characterization of the opsonic and protective activity against Staphylococcus aureus of fully human monoclonal antibodies specific for the bacterial surface polysaccharide polyNacetylglucosamine. Infect Immun. 2006 May; 74 (5): 2742-50. DOI: 10.1128/IAI.74.5.2742-2750.2006

25. Hazenbos WL, Kajihara KK, Vandlen R, Morisaki JH, Lehar SM, Kwakkenbos MJ et al. Novel staphylococcal glycosyltransferases SdgA and SdgB mediate immunogenicity and protection of virulence-associated cell wall proteins. PLoS Pathog. 2013; 9 (10): e1003653. DOI: 10.1371/journal.ppat.1003653.

26. Palliyil S, Downham C, Broadbent I, Charlton K, Porter AJ. Highsensitivity monoclonal antibodies specific for homoserine lactones protect mice from lethal Pseudomonas aeruginosa infections. Appl Environ Microbiol. 2014 Jan; 80 (2): 462-9. DOI: 10.1128/ AEM.02912-13.

27. Palliyil S. Generation of High-Sensitivity Monoclonal Antibodies Specific for Homoserine Lactones. Methods Mol Biol. 2018; 1673: 325-52. DOI: 10.1007/978-1-4939-7309-5_25.

28. Varshney AK, Wang X, Maclntyre J, Zollner RS, Kelleher $K$, Kovalenko OV et al: Humanized staphylococcal enterotoxin B (SEB)-specific monoclonal antibodies protect from SEB intoxication and Staphylococcus aureus infections alone or as adjunctive therapy with vancomycin. J Infect Dis. 2014 Sep 15 210 (6): 973-81. DOI: 10.1093/infdis/jiu198.

29. Hilliard JJ, Datta V, Tkaczyk C, Hamilton M, Sadowska A, JonesNelson $O$ et al. Anti- alpha toxin monoclonal antibody and antibiotic combination therapyimproves disease outcome and accelerates healing in a Staphylococcus aureus dermonecrosis model. Antimicrob Agents Chemother. 2015 Jan; 59 (1): 299309. DOI: 10.1128/AAC.03918-14.

30. Zou L, Liu M, Wang Y, Lu J, Pang Y. Determination of in vitro synergy between linezolid and other antimicrobial agents against Mycobacterium tuberculosis isolates. Tuberculosis (Edinb). 2015 Dec; 95 (6): 839-42. DOI: 10.1016/j.tube.2015.07.003.
31. Berditsch $M$, Jäger $T$, Strempel $N$, Schwartz T, Overhage J, Ulrich AS. Synergistic effect of membrane-active peptides polymyxin $B$ and gramicidin $S$ on multidrug-resistant strains and biofilms of Pseudomonas aeruginosa. Antimicrob Agents Chemother. 2015 Sep; 59 (9): 5288-96. DOI: 10.1128/ AAC.00682-15.

32. Krishnamoorthy G, Leus IV, Weeks JW, Wolloscheck D, Rybenkov W, Zgurskaya HI. Synergy between Active Efflux and Outer Membrane Diffusion Defines Rules of Antibiotic Permeation into Gram-Negative Bacteria. MBio. 2017; 8 (5): e01172-17. DOI: 10.1128/mBio.01172-17.

33. Omarova EO, Nazarov PA, Firsov AM, Strakhovskaya MG, Arkhipova AY, Moisenovich MM et al. Carboranyl-Chlorin e6 as a Potent Antimicrobial Photosensitizer. PLoS One. 2015; 10 (11): e0141990. DOI: 10.1371/journal.pone.0141990.

34. Maliszewska I, Kałas W, Wysokińska E, Tylus W, Pietrzyk N, Popko $\mathrm{K}$ et al. Enhancement of photo-bactericidal effect of tetrasulfonated hydroxyaluminum phthalocyanine on Pseudomonas aeruginosa. Lasers Med Sci. 2018 Jan; 33 (1): 79-88. DOI: 10.1007/s10103-017-2337-0.

35. Fekrazad R, Zare H, Vand SM. Photodynamic therapy effect on cell growth inhibition induced by Radachlorin and toluidine blue O on Staphylococcus aureus and Escherichia coli: An in vitro study. Photodiagnosis Photodyn Ther. 2016 Sep;15: 213-7. DOI: 10.1016/j.pdpdt.2016.07.001.

36. Sperandio FF, Huang YY, Hamblin MR. Antimicrobial photodynamic therapy to kill Gram-negative bacteria. Recent Pat Antiinfect Drug Discov. 2013 Aug; 8 (2): 108-20.

37. Мирошников К. А., Чертков О. В., Назаров П. А., Месянжинов В. В. Пептидо-гликанлизирующие ферменты бактериофагов - перспективные противобактериальные агенты. Успехи биологической химии. 2006; 46: 65-98.

38. Suttle CA. Marine viruses--major players in the global ecosystem. Nat Rev Microbiol. 2007 Oct; 5 (10): 801-12. DOI: 10.1038/ nrmicro1750

39. Wittebole X, De Roock S, Opal SM. A historical overview of bacteriophage therapy as an alternative to antibiotics for the treatment of bacterial pathogens. Virulence. 2014 Jan 1; 5 (1): 226-35. DOI: 10.4161/viru.25991.

40. Twort FW. An investigation on the nature of ultramicroscopic viruses. Lancet. 1915 Dec 4; (4814): 1241-3.

41. D'Herelle F. Sur un microbe invisible antagoniste des bacilles dysentériques. C R Acad Sci (Paris). 1917; 165: 373-5. French.

42. Bruynoghe R., Maisin J. Essais de thérapeutique au moyen du bacteriophage. C R Soc Biol. 1921: 85: 1120-1. French.

43. Barrow PA, Soothill JS. Bacteriophage therapy and prophylaxis: rediscovery and renewed assessment of potential. Trends Microbiol. 1997 Jul; 5 (7): 268-71. DOI: 10.1016/S0966842X(97)01054-8.

44. Sulakvelidze A, Alavidze Z, Morris JG Jr. Bacteriophage Therapy. Antimicrob Agents Chemother. 2001 Mar; 45 (3): 649-59. DOl: 10.1128/AAC.45.3.649-659.2001.

45. Skurnik M, Strauch E. Phage therapy: facts and fiction. Int J Med Microbiol. 2006 Feb; 296 (1): 5-14. DOl: 10.1016/j. ijmm.2005.09.002.

46. Lin DM, Koskella B, Lin HC Phage therapy: An alternative to antibiotics in the age of multi-drug resistance. World $\mathrm{J}$ Gastrointest Pharmacol Ther. 2017 Aug 6; 8 (3): 162-173. DOI: 10.4292/ wjgpt.v8.i3.162.

47. Levin B, Bull JJ. Phage therapy revisited: the population biology of a bacterial infection and its treatment with bacteriophage and antibiotics. Am Naturalist. 1996; 147: 881-98.

48. Rea K, Dinan TG, Cryan JF The microbiome: A key regulator of stress and neuroinflammation. Neurobiol Stress. 2016 Oct; 4: 23-33. DOI: 10.1016/j.ynstr.2016.03.001.

49. Mai V, Ukhanova M, Reinhard MK, Li M, Sulakvelidze A. Bacteriophage administration significantly reduces Shigella colonization and shedding by Shigella-challenged mice without deleterious side effects and distortions in the gut microbiota. Bacteriophage. 2015 Aug; 5 (4): e1088124. DOI: 10.10180/21597081.2015.1088124.

50. Galtier M, De Sordi L, Maura D, Arachchi H, Volant S, Dillies MA et al. Bacteriophages to reduce gut carriage of antibiotic resistant 
uropathogens with low impact on microbiota composition. Environ Microbiol. 2016 Jul; 18 (7): 2237-45. DOI: 10.1111/14622920.13284

51. Servick K. Drug development. Beleaguered phage therapy trial presses on. Science. 2016 Jun 24; 352 (6293): 1506. DOl: 10.1126/science.352.6293.1506.

52. Bourdin G, Navarro A, Sarker SA, Pittet AC, Qadri F, Sultana S et al. Coverage of diarrhoea-associated Escherichia coli isolates from different origins with two types of phage cocktails. Microb Biotechnol. 2014 Mar; 7 (2): 165-76. DOI: 10.1111/17517915.12113

53. Sarker SA, Sultana S, Reuteler G, Moine D, Descombes P, Charton $\mathrm{F}$ et al. Oral Phage Therapy of Acute Bacterial Diarrhea with Two Coliphage Preparations: A Randomized Trial in Children from Bangladesh. EBioMedicine. 2016 Jan 5; 4: 124-37. DOl: 10.1016/j.ebiom.2015.12.023

54. Latz S, Wahida A, Arif A, Häfner H, Hoß M, Ritter Ket al. Preliminary survey of local bacteriophages with lytic activity against multi-drug resistant bacteria. J Basic Microbiol. 2016 Oct; 56 (10): 1117-23. DOI: 10.1002/jibm.201600108.

55. Abedon ST. Ecology of Anti-Biofilm Agents I: Antibiotics versus Bacteriophages. Pharmaceuticals (Basel). 2015 Sep 9; 8 (3): 525-58. DOI: 10.3390/ph8030525.

56. Gabisoniya TG, Loladze MZ, Nadiradze MM, Chakhunashvili NK, Alibegashvili MG, Tamarashvili NG et al. Effects of bacteriophages on biofilm formation by strains of Pseudomonas aeruginosa. Appl Biochem Microbiol. 2016; 52: 293-7.

57. Motlagh AM, Bhattacharjee AS, Goel R. Biofilm control with natural and genetically-modified phages. World J Microbiol Biotechnol. 2016 Apr; 32 (4): 67. DOI: 10.1007/s11274-016-2009-4.

58. Brüssow H, Canchaya C, Hardt WD. Phages and the evolution of bacterial pathogens: from genomic rearrangements to lysogenic conversion. Microbiol Mol Biol Rev. 2004 Sep; 68 (3): 560-602. DOI: 10.1128/MMBR.68.3.560-602.2004.

59. Penadés JR, Chen J, Quiles-Puchalt N, Carpena N, Novick RP. Bacteriophage-mediated spread of bacterial virulence genes. Curr Opin Microbiol. 2015 Feb; 23: 171-8. DOI: 10.1016/j. mib.2014.11.019.

60. Modi SR, Lee HH, Spina CS, Collins JJ. Antibiotic treatment expands the resistance reservoir and ecological network of the phage metagenome. Nature. 2013 Jul 11; 499 (7457): 219-22. DOI: 10.1038/nature12212.

61. Quirós P, Colomer-Lluch M, Martínez-Castillo A, Miró E, Argente $M$, Jofre $J$ et al. Antibiotic resistance genes in the bacteriophage DNA fraction of human fecal samples. Antimicrob Agents Chemother. 2014; 58 (1): 606-9. DOI: 10.1128/ AAC.01684-13.

62. Colomer-Lluch M, Jofre J, Muniesa M. Antibiotic resistance genes in the bacteriophage DNA fraction of environmental samples. PLoS One. 2011 Mar 3; 6 (3): e17549. DOI: 10.1371/journal. pone.0017549.

63. Davis BM, Waldor MK. Filamentous phages linked to virulence of Vibrio cholerae. Curr Opin Microbiol. 2003 Feb; 6 (1): 35-42.

64. Broudy TB, Fischetti VA. In Vivo Lysogenic Conversion of ToxStreptococcus pyogenes to Tox+ with Lysogenic Streptococci or Free Phage. Infect Immun. 2003 Jul; 71 (7): 3782-6. DOl: 10.1128/IAl.71.7.3782-3786.2003.

65. Wang X, Wood TK. Cryptic prophages as targets for drug development. Drug Resist Updat. 2016 Jul; 27: 30-8. DOI: 10.1016/.j.drup.2016.06.001

66. Weinbauer MG. Ecology of prokaryotic viruses. FEMS Microbiol Rev. 2004 May; 28 (2): 127-81. DOI: 10.1016/j. femsre.2003.08.001.

67. Krylov VN, Pleteneva EL, Bourkaltseva M, Shaburova O, Volckaert $\mathrm{G}$, Sykilinda $\mathrm{N}$ et al. Myoviridae bacteriophages of Pseudomonas aeruginosa: a long and complex evolutionary pathway. Res Microbiol. 2003 May; 154 (4); 269-75. DOl: 10.1016/S0923-2508(03)00070-6.

68. Mesyanzhinov W, Robben J, Grymonprez B, Kostyuchenko VA Burkaltseva MV, Sykilinda NN et al. The genome of bacteriophage fKZ of Pseudomonas aeruginosa. J Mol Biol. 2002 Mar 15; 317 (1): 1-19. DOI: 10.1006/jmbi.2001.5396.

69. Hertveldt K, Lavigne R, Pleteneva E, Sernova N, Kurochkina L,
Korchevskii $\mathrm{R}$ et al. Genome comparison of Pseudomonas aeruginosa large phages. J Mol Biol. 2005 Dec 2; 354 (3): 53645. DOI: 10.1016/j.jmb.2005.08.075

70. Navarre WW, Schneewind O. Surface proteins of gram-positive bacteria and mechanisms of their targeting to the cell wall envelope. Microbiol Mol Biol Rev. 1999 Mar; 63 (1): 174-229.

71. Beveridge TJ. Structures of gram-negative cell walls and their derived membrane vesicles. J Bacteriol. 1999 Aug; 181 (16): 4725-33.

72. Delbrück M. The Growth of Bacteriophage and Lysis of the Host. J Gen Physiol. 1940; 23 (5): 643-60.

73. Leiman PG, Chipman PR, Kostyuchenko VA, Mesyanzhinov V, Rossmann MG. Three-dimensional rearrangement of proteins in the tail of bacteriophage T4 on infection of its host. Cell. 2004 Aug 20;118 (4): 419-29. DOI: 10.1016/j.cell.2004.07.022.

74. Kanamaru S, Leiman PG, Kostyuchenko VA, Chipman PR, Mesyanzhinov VV, Arisaka F et al. Structure of the cell-puncturing device of bacteriophage T4. Nature. 2002 Jan 31; 415 (6871): 553-7. DOI: 10.1038/415553a.

75. Roach DR, Donovan DM. Antimicrobial bacteriophage-derived proteins and therapeutic applications. Bacteriophage. $2015 \mathrm{Jul}$ Sep; 5 (3): e1062590. DOI: 10.1080/21597081.2015.1062590.

76. Young R. Phage lysis: do we have the hole story yet? Curr Opin Microbiol. 2013 Dec; 16 (6): 790-7. DOI: 10.1016/j. mib.2013.08.008.

77. Young R. Phage lysis: three steps, three choices, one outcome. J Microbiol. 2014 Mar; 52 (3): 243-58. DOI: 10.1007/s12275-0144087-z

78. Henrissat B. A classification of glycosyl hydrolases based on amino acid sequence similarities. Biochem J. 1991 Dec 1; 280 (Pt 2): 309-16.

79. Henrissat B, Bairoch A. Updating the sequence-based classification of glycosyl hydrolases. Biochem J. 1996 Jun 1; 316 (Pt 2): 695-6.

80. Blackburn NT, Clarke AJ. Identification of four families of peptidoglycan lytic transglycosylases. J Mol Evol. 2001 Jan; 52 (1): 78-84.

81. Höltje JV. Lytic transglycosylases. EXS. 1996; 75: 425-9.

82. Fastrez J. Phage lysozymes. EXS. 1996; 75: 35-64.

83. Weaver LH, Grütter MG, Remington SJ, Gray TM, Isaacs NW, Matthews BW. Comparison of goose-type, chicken-type, and phage-type lysozymes illustrates the changes that occur in both amino acid sequence and three-dimensional structure during evolution. J Mol Evol. 1984-1985; 21 (2): 97-111.

84. Monzingo AF, Marcotte EM, Hart PJ, Robertus JD. Chitinases, chitosanases, and lysozymes can be divided into procaryotic and eucaryotic families sharing a conserved core. Nat Struct Biol. 1996 Feb; 3 (2): 133-40.

85. Jaeger T, Arsic M, Mayer C. Scission of the lactyl ether bond of $\mathrm{N}$-acetylmuramic acid by Escherichia coli "etherase". J Biol Chem. 2005 Aug 26; 280 (34): 30100-6. DOI: 10.1074/jbc. M502208200

86. Díaz E, López R, García JL. Chimeric phage-bacterial enzymes: a clue to the modular evolution of genes. Proc Natl Acad Sci U S A. 1990 Oct; 87 (20): 8125-9.

87. Desiere $F$, Lucchini $\mathrm{S}$, Brüssow $\mathrm{H}$. Evolution of Streptococcus thermophilus bacteriophage genomes by modular exchanges followed by point mutations and small deletions and insertions. Virology. 1998 Feb 15; 241 (2): 345-56.

88. Sheehan MM, Stanley E, Fitzgerald GF, van Sinderen D. Identification and Characterization of a Lysis Module Present in a Large Proportion of Bacteriophages Infecting Streptococcus thermophilus. Appl Environ Microbiol. 1999 Feb; 65 (2): 569-77.

89. Hermoso JA, Monterroso B, Albert A, Galán B, Ahrazem O, García $P$, et al. Structural basis for selective recognition of pneumococcal cell wall by modular endolysin from phage $\mathrm{Cp}-1$. Structure. 2003 Oct; 11 (10): 1239-49.

90. López R, García E, García P, García JL. The pneumococcal cell wall degrading enzymes: a modular design to create new lysins? Microb Drug Resist. 1997 Summer; 3 (2): 199-211.

91. Gilmer DB, Schmitz JE, Euler CW, Fischetti VA. Nove bacteriophage lysin with broad lytic activity protects against mixed infection by Streptococcus pyogenes and methicillin- 
resistant Staphylococcus aureus. Antimicrob Agents Chemother. 2013 Jun; 57 (6): 2743-50. DOI: 10.1128/AAC.02526-12.

92. Yang H, Wang DB, Dong Q, Zhang Z, Cui Z, Deng J et al. Existence of separate domains in lysin PlyG for recognizing Bacillus anthracis spores and vegetative cells. Antimicrob Agents Chemother. 2012 Oct; 56 (10): 5031-9. DOI: 10.1128/AAC.00891-12.

93. Loeffler JM, Fischetti VA. Synergistic lethal effect of a combination of phage Iytic enzymes with different activities on penicillinsensitive and -resistant Streptococcus pneumoniae strains. Antimicrob Agents Chemother. 2003 Jan; 47 (1): 375-7. DOI: 10.1128/AAC.47.1.375-377.2003.

94. Fischetti VA Bacteriophage lytic enzymes: novel anti-infectives. Trends Microbiol. 2005 Oct; 13 (10): 491-6. DOI: 10.1016/j. tim.2005.08.007.
95. Yang H, Zhang Y, Yu J, Huang Y, Zhang XE, Wei H. Novel chimeric lysin with high-level antimicrobial activity against methicillinresistant Staphylococcus aureus in vitro and in vivo. Antimicrob Agents Chemother. 2014; 58 (1): 536-42. DOI: 10.1128/ AAC.01793-13

96. Djurkovic S, Loeffler JM, Fischetti VA. Synergistic killing of Streptococcus pneumoniae with the bacteriophage lytic enzyme Cpl-1 and penicillin or gentamicin depends on the level of penicillin resistance. Antimicrob Agents Chemother. 2005 Mar; 49 (3): 1225-8. DOI: 10.1128/AAC.49.3.1225-1228.2005.

97. Schmelcher M, Donovan DM, Loessner MJ. Bacteriophage endolysins as novel antimicrobials. Future Microbiol. 2012 Oct; 7 (10): 1147-71. DOI: 10.2217/fmb.12.97. 